Милица Абрамовић

Универзитет у Београду

Филолошки факултет
821.111(73).09-31 Вонегат К. https://doi.org/10.18485/climb.2017.5.2.ch12

\title{
НАУКА И ФИКЦИЈА У НАУЧНОЈ ФАНТАСТИЦИ КУРТА ВОНЕГАТА
}

\section{Сажетак}

Курт Вонегат обилато користи елементе научне фантастике да пародира егзистенцијалну кризу постмодерне индивидуе која се у разумевању реалности више не може уздати само у Бога или науку. Романи Сврачје ноге и Механички пијанино су јасни примери судара науке и културе, наставши у периоду када су браћа Вонегат радила за исту компанију - Курт при сектору односа са јавношћу, а Бернард као водећи научник лабораторије Kућа магије. Деконструкција елемената научне фантастике и окружења које је условило настанак гореспоменутих романа указује на специфични однос науке и фикције у овој постмодерној кући магије.

Кључне речи: наука, фикција, научна фантастика, постмодернизам, Вонегат

\section{1. Развој жанра научне фантастике}

Са осамнаестим веком и добом разума јавља се друштвена свест која омогућава појаву жанра научне фантастике. Прихватају се емпиричка уместо митолошких објашњења и ауторитет свемогућег Бога бива замењен законима природе. Као почетак научне фантастике узима се Мери Шелин (Mary Shelley) Франкенштајн (Frankenstein) из 1818. године који илуструје овај однос науке и Бога. Франкенштајново чудовиште је чудовиште зато што је настало уз помоћ закона науке и научних метода који су у директној супротности деловањима божанственог/Бога. Рана дела научне фантастике се базирају на страху од науке и научних открића, али истовремено илуструју човекову борбу са новим начином разумевања реалности који наука пружа. 
Деветнаести век означава померање ауторитета са Бога на науку. Тада Ниче изјављује да је Бог мртав - иако ће божја сенка успети да опстане у неким пукотинама још хиљадама година, научна открића дозвољавају и верницима велику дозу скептицизма. Чак и Велсова (H.G.Wells) дела, која представљају сазревање научне фантастике од раних дела ка модерним, имају сличности са ранијим периодом иако директно не упозоравају на опасност превласти науке над Богом. Импликација Pama светова (The War of the Worlds 1898) је да наука помаже, али недовољно - Бог нас мора напослетку избавити. Модерно доба представља другу фазу у развоју научне фантастике у којој се уместо науке религија сматра инфериорним начином размишљања зарад своје аверзије према емпиријским методологијама. Артур Кларк (Arthur C. Clarke) у роману Kрај детињства (Childhood's End 1953) слика друштво у будућности у којем су ванземаљске силе преузеле власт и створиле утопију на Земљи. Све религијске групе нестају зато што, у оваквом друштву, наука и образовање постају ауторитет - само одбацивањем митова људска врста може да напредује/ опстане. Мир на Земљи постигнут је напуштањем старих наратива и прихватањем науке. Величање науке, карактеристично за модерно доба, није дуго потрајало. Атомско бомбардовање Хирошиме и Нагасакија разочарава генерацију и указује на могућу неморалну употребу науке. Егзистенцијализам се јавља као једини резултат света у коме наука више није утеха. У делима као што су Цвеће за Алиернона (Flowers for Algernon 1959) аутора Данијела Киза (Daniel Keyes) и Хладне једначине (The Cold Equations 1954) аутора Тома Годвина (Tom Godwin) људи су само жртве напретка науке - она њима мало помаже, док они страдају. Главни лик Кизовог текста је жртва нехуманог експеримента - новом хирушком методом коефицијент интелигенције му је повећан са 68 на 185, само да би се на крају вратио на старо. Јунакиња Годвиновог текста страда због математичке једначине која израчуна да ако она умре осморо људи ће преживети. Овакви текстови показују нови став према науци као неосетљивој према људским осећањима. Уместо утопије добили смо свет у коме човек више није центар универзума и мора да се бори против свог окружења, поново. Курт Вонегат (Kurt Vonnegut) се тиме бави у роману Галапагос (Galápagos 1985) описујући друштво људи који полако постају налик 
Култура и/или наука

морским бићима услед природног закона селекције. Природа је владала човеком у раном добу, човек природом у модерном добу, док у постмодерном добу човек постаје само још један део природе. Постнуклеарни хероји су ништа више до самотњаци чији животи стално трпе нападе разних неумољивих сила међу којима је и наука. За разлику од два претходна периода развоја жанра научне фантастике, у постнуклеарном добу индивидуа и индивидуална слобода постају од кључног значаја и супериорни су у односу на утицај Бога или науке. У роману Сврачје ноге (Cat's Cradle 1963) Вонегат представља читаоцима једну такву персону. Главни лик Феликс Хоникер је самотњак, предани научник, чији је једини циљ унапређење науке. Његово откриће леда-9 има катастрофалне последице. За разлику од Франкенштајна који ствара чудовиште уместо човека зато што се осмелио да се меша у божија посла, Хоникерово откриће уништава свет због закона физике који су равнодушани према људским жртвама. Хоникерова научна радозналост завршава се тоталним уништењем. Бун указује да је „смрт представљена као закључак игре коју смо сами себи смислили." (Boon 2009: 10-20)

\section{1. Научна фантастика и постмодернизам}

Научна фантастика се у постнуклеарном добу повезује са постмодернизмом стога што научнофантастични футуризам има много тога заједничког са постмодернизмом - најпре прати развој технологије, а онда и њен утицај на културу. Научна фантастика је слична постмодернизму и по томе што су оба појма проблематична за дефинисање. Робертс сматра да је научна фантастика жанр у коме се приказује фикционални свет на неки начин другачији од нашег (на пример: друштво у будућности, ванземаљци, путовања на друге планете итд). Робертсонова дефиниција је опширна зато што детаљније постављање дистинкција између научне фантастике и других врста фантастичног дискурса постаје веома проблематично. (Roberts 2006: 1) Дефиниције постмодернизма су такође бројне и разнолике Маус посматра постмодернизам из неколико перспектива. Прво наводи обухватнију и широко прихваћену дефиницију по којој је пост- 
модернизам одговор на Други светски рат, Холокауст и светску трку у производњи нуклеарног оружја. Супротно овом постоји став да је постмодернизам заправо конкретно уметнички покрет који је одговор на модернизам. Постоје и инклузивнији покушаји дефинисања, као они који подразумевају да је постмодернизам начин размишљања који спаја науку и уметност, на тај начин повезујући идеје које су се до тада гледале одвојено. (Maus 2001: 11-19) Оваква немогућност да се дефинише како жанр научне фантастике тако и сам постмодернизам чини се веома неуобичајеном стога што већина читалаца има осећај шта ови појмови значе, а истовремено их не могу конкретно дефинисати.

Постмодернистички аутори увиђају значај науке у постмодерном добу и неки од њих, међу њима и Вонегат, бивају фасцинирани науком, њеним развојем и могућим импликацијама тог развоја. Међутим, однос науке и постмодерне књижевности је у основи нестабилан - Урсула Хаиз сматра да је њихов однос негде на линији између технофобије и утопије. Овај проблематични однос потиче из компликованог односа науке и књижевности. Писци и критичари сматрају да се књижевност базира на емоцијама, интуицији и машти насупрот науци која се наводно користи механичким објашњењима. Наука и технологија се одувек у књижевности појављују у контексту пропасти света због њихове злоупотребе - апокалиптични сценарији постају чести у постмодерном свету у којем је ризик од нуклеарног уништења и критичног загађења животне средине све већи. У савременој књижевности преовладава песимизам у вези са утицајем науке на друштво било то кроз слику света после нуклеарне катастрофе или пренасељене и драстично загађене животне средине често приказане у романима научне фантастике. Однос науке и књижевности се значајно мења у савременом добу у којем наука постаје мање искључива по питању разумевања реалности. Књижевност се такође мање бави својом улогом и дозвољава шири опсег тема брисањем граница између високе и популарне културе. Како технологија помаже у раду и научницима и уметницима тако се и јаз између науке и уметности полако сужава. Иако повезује технологију са апокалипсом у неким контекстима, постмодерна књижевност слави потенцијал науке да унапреди ум, тело и културу. Оно што је ужасавало претходне генерације писаца сада се посматра у новом свет- 
Култура и/или наука

лу - наука и технологија постају решење и нада да се људи могу ослободити ограничења која им сопствена тела, биологија или култура намећу. Писци као што су Пинчон (Thoman Pynchon) или ДеЛило (Don DeLillo) одређена своја дела базирају око принципа термодинамике и информационе теорије и описују друштва у тој мери презасићеним технологијом да могу наизменично имати претећи и ослобађајући карактер (Хаиз 1997), други писци, као што је Вонегат, преиспитују напредак и његову потенцијалну цену, док се трећи у потпуности окрећу жанру научне фантастике.

\section{2. Вонегатова проза и научна фантастика}

Вонегат је најпре постмодернистички писац иако је често окарактерисан као писац научне фантастике због елемената тог жанра које обилато користи у својим делима: опера у свемиру у Сиренама са Tитана (The Sirens of Titan 1959), путовања кроз време или на ванземаљске планете у Кланици Пет (Slaughterhouse Five 1969), апокалипса у Сврачјим ногама (Cat's Cradle 1963), утопијско друштво у Механичком пијанину (Player Piano 1952) итд. Елементи које бисмо назвали научнофантастичним су пародијске скице земаљских проблема у постмодерном добу и њихових могућих последица. Још од својих првих приповедака Вонегат посеже за темама и мотивима научне фантастике како би пародирао одређене аспекте америчке културе. Његов први роман брзо постаје етикетиран као роман научне фантастике - утопијско друштво у будућности је карактеристично научнофантастични мотив. Делимично одговорним за ово можемо сматрати период када је Вонегат радио у некој врсти утопијског окружења константног научног напредовања, у компанији Џенерал електрик (General Electric), које је понудило инспирацију за ликове, локације и теме. Џинџер Странд (Ginger Strand) пише упоредо биографије Курта и Бернарда Вонегата, са посебним фокусом на време када су истовремено радили у истој компанији - период који је обликовао идентитет обојице и представљао прекретницу у њиховим животима.

Пореклом из утицајне породице интелектуалаца из Индијанаполиса, од Курта се много очекивало. Док је његов брат Бер- 
нард био надарен за природне науке, сестра Алис за музику, Курт је морао да развија смисао за хумор, што му се исплатило још у средњој школи када је почео да пише рекламе за локалне новине. Био је то посао у коме је уживао, све време свестан да неће моћи њиме да се бави - његов отац и брат били су се одавно сложили да Курт треба да студира природне науке, и то хемију. Управо са тих часова термодинамике, математике и машинства Курт бива послат у рат, док Бернарда од сигурног регрутовања спашава нови посао у војној лабораторији. Бернард је био убеђен да ће наука спасити свет - утабаће пут до утопије. ${ }^{1}$ Пошто се у војној лабораторији бавио проучавањем леда и временских услова, није било неуобичајено што му је по завршетку рата био понуђен посао у компанији Џенерал електрик која тада запошљава све већи број научника у циљу континуираног напретка науке. Нобеловом наградом награђени хемичар Ирвинг Ленгмјур (Irving Langmuir) и метеоролог Винсент Шејфер (Vincent Schaefer) су радили за исту компанију и бавили се проучавањем леда и проблематиком одлеђивања разних делова летелица који се при великим висинама леде и отежавају рад мотора. Иако није био метеоролог, Ленгмјур је желео да се бави проучавањем временских услова и њиховим управљањем², па показује велико интересовање за Бернардов рад и жељу да сарађују. Научнике и истраживаче у Џенерал електрику су охрабривали да раде на својим омиљеним пројектима зарад бољих резултата, тако Ленгмјур, хемичар, добија зелено светло да се бави проучавањем временских услова. (Strand 2015: 9-16) Убрзо потом се Бернард придружује Ленгмјуру и Шејферу и као тим почињу са решавањем проблема честих суша у Њујорку. Усађивањем сребро јодида у облаке, за које је процењено да ће прећи изнад сушних предела, изазвано је много пљускова представљајући тако позитивну модификацију временских услова. Научници су доказали још једном да је наука решење! Када се вест о Бернардовом експерименту и

1 Послератни оптимизам се често појављује у Вонегатовим делима као одраз послератног размишљања. Волтер Старбак, наратор романа Затворска птичица (Jailbird 1979), говори о рађању једне нове послератне ере која ће бити прекретница у историји. (Strand 2015: 261) Важно је истаћи разлику између размишљања самог аутора, с једне стране, и размишљања његових ликова или наратора, с друге.

2 Могућност управљања временским условима значила би сигурне победе у будућим ратовима. 
његовим резултатима раширила по Америци, сваки аматер који је био умогућности покушавао је да понови ефекат постигнут од стране научника. Пошто је обогаћивање облака сребро јодидом и њихово касније усмеравање зависило од праћења прецизне процедуре засноване на прикупљеним подацима о сушном пределу, ови аматерски покушаји бивају неуспешни узрокујући бројне насумичне и незабележене пљускове, а касније и поплаве. Процес прикупљања информација у циљу одређивања у којим тачно пределима, када и колико сребро јодида је усађено у облаке показало се као преопширан, незахвалан и понајвише непоуздан посао. Бернард одлучује да преузме одговорност за поплаве изазване његовим открићем и упозори јавност о могућим опасним последицама аматерског модификовања временских услова. Он није могао да дозволи да трка ка новим открићима буде важнија од интереса човечанства и тако постаје једна од главних инспирација за Курта. Након повратка из рата, Курт наставља да се школује, али мења хемију антропологијом, и убрзо и сам почиње да ради у Џенерал електрику. Као део сектора односа са јавношћу, Курт пише о открићима и доживљајима њихових научника. У мору машина ове будуће корпорације издвајала се једна лабораторија, она у којој Бернард ради на истраживању модификације временских услова. Лабораторију су звали Кућа магије - име које није импоновало научницима који су у лабораторији радили на развитку науке а не магије, али итекако је било интересантно писцима у сектору за односе са јавношћу. (ибид. 44-45)

Велики део инспирације за научнофантастичне елементе које Вонегат користи у својим делима потиче из комуникације са запосленима у Џенерал електрику и животном и радном искуству у корпоративној заједници. Огранак ове фирме у којем су радили Курт и Бернард налазио се у граду Скенектадију у држави Њујорк. Комплекс је био подељен на три дела - један за машине, други за раднике и трећи за менаџере и инжењере. У Механичком пијанину, Вонегатовом првом роману, описан је град Илијум, идентичан Скенектадију, који је познат по компанији идентичној Џенерал електрику и ликови који су верзије научника и инжењера са којима се Курт сусретао на послу - многа имена, локације, догађаји и разговори засновани су на истинитим. Једино што наговештава да је ово један научнофан- 
тастични текст јесте то што се радња одвија у ближој будућности у којој су глад и несташица превазиђени и влада утопија. Инжењери су најважнији део друштва, они су најбогатији и најцењенији из разлога што стално граде машине које замењују било какав људски напор. Машине раде даноноћно - морају обавити сав посао који су некада завршавали људи, али боље и прецизније од њих. За раднике нема више простора у новом систему. Мали број још увек има посао и то углавном на одржавању машина које ће им ускоро одузети и тај посао. За остале раднике једноставно нема посла - изједа их кривица што постоје јер не раде ништа да би то постојање имало сврху. Они су изгубили достојанство, имају све а не знају како то да оправдају. Протагонисту романа, Пола Протеуса, Вонегат је засновао на лику једног од најпопуларнијих научника у Џенерал електрику. Протеус је на завидној позицији и спреман је за напредовање. Добити унапређење значи продати душу, али једино што је важно је напредак, по којој год цени. Читаоци се упознају са Протеусом баш онда када њему овај систем почиње губити смисао и прате његов пут самоуништења у оквиру тог система. Досадиле су му машине, али и колеге које су све више налик машинама, па у тајности одлучује да се пресели на село и обрађује земљу. Сазнавши то, надређени му честитају на иницијативи да се инкогнито придружи револуционарима и уништи их изнутра. Избор је његов - да се заиста придружи и помогне револуцији против оваквог система или да уништи револуцију. Странд повлачи паралелу између овог Вонегатовог романа и неколико веома популарних књижевних дела тог времена. Одлос Хаксли (Aldous Huxley) у роману Врли нови свет (Brave New World 1932) описује друштво у будућности у којем се људи производе са испраним мозговима како би се што боље уклопили у строги систем друштвене хијерархије. Џорџ Орвелов (George Orwell) роман 1984 из 1949. године бави се сличним питањима испирања мозгова у друштву у коме се ликови морају повиновати размишљању групе због константног стања присмотре и рата. Супротно од ових аутора, Вонегат у Механичком пијанину гради утопијску будућност чија највећа последица је то што су машине замениле људе у већини послова. Хакслијев и Орвелов наратив налазе наду у успеху револуције или тотално очајање у њеном неуспеху. Покушај главног лика Врлог новог света да побегне из система води до 
Култура и/или наука

његовог изгнанства, а револуција главног лика 1984 има као последицу тешку казну и преваспитавање. Механички пијанино иде корак даље и поручује да казне, преваспитавања и изгнанство заправо уопште нису потребни, јер револуција постоји само у главама побуњеника. Одмах по успеху револуције они се враћају изградњи управо оне технологије против које су се борили, зато што је она ипак превише заводљива. (ибид. 203; 224) Вонегат приказује друштво не тако далеке будућности у којем обични људи губе достојанство зарад машина чија је намена била да људима врате достојанство поштедевши их тешких послова. Протеус, између осталих, учествује у стварању света без несташице и неефикасности, не размишљајући о потенцијалној цени таквог напретка. Ове сјајне машине, лажни богови, заузеле су кључна места у животима обичних људи и од њих направиле робове, или нешто можда чак супротно од робова - људе без сврхе који имају сву слободу, али не знају шта ће с њом. Овај текст нема за циљ изазивање технофобије, али се чини као да упозорава читаоце на последице напретка технологије, не зато што је она неопходно лоша, већ зато што човек није свестан последица таквог напретка - пут у потпуни бесмисао биће поплочан најбољим намерама. Међутим, најважнији део романа јесте када се револуционари погрбе како би обновили уништену технологију. Вонегат се у Механичком пијанину не бави апокалиптичким сценаријима, нити упозоравањем на последице развоја технологије и науке. Он обрађује тему парадоксалне људске природе - човек жели да буде слободан, али истовремено му је неопходан ауторитет који би иначе бесмисленом човековом постојању дао неки смисао. Иако се човек бори против ауторитета, у облику Бога, науке или технологије, њему је он од животне важности. Роман се завршава призором побуњеника којима услед рушења ауторитета технологије не преостаје ништа друго него да је поново саграде. Као што Килгор Траут, главни лик романа Доручак шампиона (Breakfast of Champions 1973) и Вонегатов литерарни алтер его, каже - ако птици даш три жеље, једна ће бити да јој отвориш врата кавеза, друга да отвориш спољна врата, а трећа је да је вратиш назад у кавез (Vonnegut 2000: 35).

Роман Сврачје ноге Курт развија из приповетке коју годинама покушава да заврши - требало је да прође скоро деценија да се идеја у потпуности развије и да се права порука романа обликује. Причу 
о научнику Курт претвара у причу о причама у којој главни лик и наратор Џона пише књигу о бомбардовању Хирошиме и, у стилу популарне културе, истражује шта су познате личности радиле тог дана. Истраживање почиње у граду Илијуму где је познати научник Феликс Хоникер својим радом био допринео настанку атомске бомбе. Иза Хоникера остају његова деца и чувају његов најновији изум тј. нову варијанту леда, лед-9, који леди све са чиме дође у контакт и остаје залеђен и при веома високим температурама. Наратор Џона и Хоникерова деца, Френклин, Анџела и Њут, завршавају на фикционалном острву Сан Лорензо, са по бочицом леда-9, најстрашнијег оружја масовног уништења познатог човечанству. Ту упознају диктатора ове државе који болује од рака и који моли Френклина, генијалног научника, да преузме улогу следећег владара на острву. Убеђен да је себи нашао замену и не желећи да изгуби достојанство, доктатор Сан Лоренза извршава самоубиство ледом-9. Несрећним сплетом околности, његово тело доспева у океан који се истог тренутка леди у потпуности, као што лед-9 и обећава. Услед општег уништења, Џона се може заштитити само у бункеру у коме пише касније своје мемоаре односно приповеда роман Сврачје ноге. Сличност ликова, локације и догађаја у овом роману и реалном животу нам показује још једном да Вонегат није у послу писања научне фантастике. Град Илијум је у ствари Скенектади, Феликс Хоникер је заправо Ирвинг Ленгмјур, а Хоникерово откриће леда-9 је Ленгмјурова замисао. Странд сматра да Вонегат помера акценат са Хоникера на његову децу када поставља Џону за наратора. Тешко је занемарити очигледну сличност не само између имена Вонегат и Хоникер, већ и између Хоникерове деце и Вонегатове породице. Френклин, предани и генијални научник, је нико други до Бернард; Анџела, прелепа уметница, је Алис; а Њут, мрзовољни патуљак који се бави сликањем, је Курт. (Strand 2015: 238)

Централни део овог романа представља уништење планете новом врстом леда којег је Хоникер развио са намером да буде од помоћи војсци - када војници прелазе преко мокрих и блатњивих површина могли би да употребе лед-9 да нестабилна површина очврсне олакшавајући кретање. Овај изум нажалост није имао ефекат каквом се Хоникер надао. После његове смрти, његова деца чувају лед-9 док ситуација не измакне контроли. Идеју за овај изум Воне- 
Култура и/или наука

гат добија за време рада у Џенерал електрику, јер у сектору за одноce ca јавношћу Вонегату је посао био да записује интересантне догодовштине њихових научника - јавност је морала добијати дозу шашавих научника како не би бринула о томе чиме се они заправо баве. (Strand 2015: 96) Неки извори кажу да је Велс (H.G.Wells) дошао у посету компанији када му је Ленгмјур, са намером да га забави, понудио идеју о леду-9, опасној варијацији леда која се топи само на екстремно високим температурама. Вонегат је једном приликом изјавио да је идеју присвојио након што су обојица, Ленгмјур и Велс, умрли, а нису се даље позабавили њоме. Иако је додатно проверио ову теорију са стручњацима и добио негативан одговор што се тиче њене изводљивости, Вонегат одлучује да је употреби. Каже да је лед9 скоро подједнако лош као и многа тадашња открића и да зато има „моралну валидност“ потребну за оно што жели да каже. Мекгинис сматра да је погрешно гледати на овај роман као на роман научне фантастике или као на чисту критику тадашњег друштва, јер има превише доказа који тумачење усмеравају у другом правцу. Интертекстуалне референце на Стари завет су директне и јасне. Мекгинис тврди да ако не сматрамо научном фантастиком Јонин однос са Богом нити посматрамо причу о Јони само као социјалну критику, онда то не можемо радити ни са овим Вонегатовим романом. Лед-9 у овом контексту представља симбол зла који је научно најближи другом закону термодинамичког схватања ентропије. Мекгинис закључује да смо доста на Вонегата гледали као на писца научне фантастике или критичара друштва - он коначно треба да заузме место у „универзалној моралној арени где му је и место“. (McGinnis 1974: 40-41)

Боконон, оснивач забрањене религије бокононизма на острву Сан Лорензо, је својеврсна антитеза Хоникеру. Лик Хоникера је заснован на Ленгмјуру, научнику који никада није бринуо о томе у које сврхе ће његови изуми бити употребљени, већ је само задовољавао своју радозналост радећи на изумима од којих су неки касније имали катастрофалне последице - он је скица једног од научника који су допринели настанку атомске бомбе. Боконон представља Хоникерову супротност зато што се бави проповедањем религиозног наратива којег је сам написао и признаје да приповеда лажи само да би народу донео мало утехе. Странд каже да Боконон пружа „алтернативу сте- 
рилном технолошком веровању у истину“ Феликса Хоникера. Вонегат овим читаоцима поручује нешто што је одавно научио од Достојевског - да Бог не постоји морали бисмо га измислити. Стварањем бокононизма Вонегат каже да ако већ измишљамо Бога зашто онда не бисмо изабрали једног који је пун љубави и разумевања и који нас наводи да пронађемо нешто свето управо у себи. Странд сматра да праву претњу у овом роману не представљају научници нити неки њихов потенцијани изум, као што већина критичара тврди. Хоникер није негативац зато што долази до открића леда-9, већ зато што не упозорава никога о постојању тако опасне супстанце. Само он зна колико је његов изум опасан и морална му је обавеза да о томе обавести остатак света. Уосталом, Бернард Вонегат је учинио исто по питању непредвиђених последица аматерске модификације временских услова, па чак и преузео одговорност. (Strand 2015: 237-239) О моралној обавези научника пише и савременик браће Вонегат, математичар Норберт Венер (Norbert Wiener), који изјављује да неће поделити своја открића уколико се покаже да се могу користити као оружје и позива остале научнике да ураде исто. (ibid. 114) Научници постају арбитри живота и смрти - уколико информишу јавност о изумима/подацима/ открићима који могу бити упоребљени као или допринети настанку оружја, онда у будућности треба очекивати њихову употребу у те сврхе.

\section{3. Вонегат - проповедник или приповедач?}

Неслога око тога да ли су ови романи научнофантастични или не потиче из саме несигурности око дефинисања овог жанра. Вонегат је наизменично прихватао и одбацивао ову етикету управо због сталних промена концензуса око тога шта је заправо научна фантастика и које су то конкретне одлике овог жанра. Вонегат је био сигуран да није писао научну фантастику, бар не у класичном смислу, али јесте писао фикцију о науци, могућим последицама развоја науке, и људској природи која је можда предвидљивија од последица напретка науке. Механички пијанино и Сврачје ноге су примери управо такве фикције, а не текстови упозорења о негативним последицама развоја 
Култура и/или наука

науке и технологије, као што један број критичара тврди, нити говоре о моралној обавези научника да о својим потенцијално опасним изумима обавести јавност, као то тврди Џинџер Странд. Механички пијанино приказује друштво у којем су све основне потребе његових чланова задовољене, али то се испоставља као недовољно. У оваквом систему само мали број људи живе смислене животе, док остали не могу пронаћи себи место унутар система. Нису машине одузеле човеку достајанствно, то је урадио човек када је одлучио да прави машине како би свом постојању дао смисао. Научник није неопходно антагониста, он је само човек, али на овај начин наставља зачарани круг потраге за смислом и губљења свог смисла. Роман се завршава револуцијом, или је можда исправније рећи пародијом револуције одмах по завршетку немира, у којем је велики део технологије уништен, побуњеници одмах почињу са обновом технологије и машина које су до малочас уништавали. Ови Вонегатови романи нису ни текстови упозорења о могућем крају света, нити лекције којима треба учити научнике. Вонегат се школовао да буде антрополог - онај који проучава прошла и садашња друштва и који на основу знања и разумевања која има о човеку и људској природи може направити претпоставке о потенцијалним недостацима могућих друштвених система у будућности. Те претпоставке се базирају на схемама људског понашања које су цикличне и на тај начин донекле предвидљиве. Механички пијанино није изграђен на научнофантастичној основи, нема за циљ да нам покаже једно крајње необично друштво у будућности, нити служи као проповед о потенцијалним последицама убрзаног развоја науке и технологије. Напротив, овај текст илуструје зачарани круг индивидуалне и социјалне потребе за ауторитетом чак и у борби за сопствено достојанство. У овом постпостмодерном добу технологија представља једини прави ауторитет којег се друштво никада неће ослободити, првенствено зато што то уопште не жели. Сврачје ноге је роман који се веома често тумачи као текст упозорења на потенцијално катастрофалне последице научних открића, или, како Странд тврди, има за циљ да укаже на обавезу научника према друштву да обавести јавност о својим изумима који би могли имати глобално погубне последице. Странд кроз своје дело закључује да је Бернард Вонегат урадио поводом сребро јодида управо оно 
што је Хоникер требало учинити поводом свог открића леда-9. Како је Хоникер у ствари Ленгмјур, Странд каже да овим романом Вонегат поручује да научници, највише они као Ленгмјур, треба да имају ширину и разумевање, ако не и хуманост, попут његовог брата Бернарда. Међутим, Бернард није био у ситуацији сличној Хоникеровој. Бернарад је са својим тимом открио могућност модификовања временских услова усађивањем одређених супстанци у облаке који прелазе преко сушних предела. Аматери су желели да буду хероји, али неконтролисано спровођење нечега што су научници примењивали у контролисаним условима је на крају проузроковало огромне поплаве широм регина. Бернард тада одлучује да јавност мора бити упозорена. С друге стране, Хоникер, који је дошао до опасног открића које може да уништи целу планету, одлучује на никога не обавести, а посебно не јавност. После Хоникерове смрти његова деца продају по мало леда-9 иако знају да уништава све са чиме дође у контакт. Последице леда-9 биле би исте и да је Хоникер упозорио друштво о његовом дејству. Тада би лед-9 био одузет научницима и вероватно одложен на сигурну владину локацију што би само омогућило лакшу употребу овог оружја масивног уништења. Јавност је знала какве последице има атомска бомба, па није бачена једна, већ две. Читаоцу се може чинити да Вонегат апелује на научнике да би, уколико дођу до сазнања која би било могуће употребити као оружје, најбоље било држати их у тајности. Међутим, пример Хоникерове ситуације показује да ако научници одмах не униште потенцијално опасна отрића и изуме, будуће генерације ће их сигурно употребити. Наука не настаје у вакууму, па је огромна вероватноћа да ће научник на другом крају света доћи до истих сазнања и закључака. Завршетак романа Сврачје ноге је пример краја још једног циклуса - човек ће уништити ову планету и при томе ће много људи страдати, било то изумом као што је лед-9 или континуираним напором. Деконструкција елемената научне фантастике и анализа романа као што су Механички пијанино и Сврачје ноге указују на Вонегата као писца који посматра друштво из антрополошке перспективе и пише о могућим варијантама будућности базираним на актуелним проблемима у Америци и свету. Вонегат се користи елементима научне фантастике као помоћним средством које ће његове романе приближити 
Култура и/или наука

жанру популарне културе и тако привући читаоце и их истовремено навести на размишљање о човечанству, његовим навикама, и о томе да ли оно може ићи против своје природе. Вонегатово разумевање значаја науке и технологије му омогућава да деконструише постмодерне проблеме - он је антрополог и проповедач, а не проповедник краја света.

\section{Извори и литература:}

Boon, Kevin Alexander. "Episteme-ology of Science Fiction". Donald E. Morse (ed.). Anatomy of Science Fiction. Newcastle: Cambridge Scholars Publishing, 2009. 10-24. Printed.

Clarke, Arthur. C. Childhood's End. New York: Rosetta Books, 2012. Printed.

Godwin, Tom. (author), Flint, Eric. (ed.). The Cold Equations \& Other Stories. North Carolina: Bean Books, 2003. Printed.

Heise, Ursula. "Between technophobia and utopia: Science and postmodern literature". 21stC, Issue 2.3 (1997). Web. 20.02.2017.

Huxley, Aldous. Brave New World. New York: Vintage Books, 2007. Printed.

Keyes, Daniel. Flowers for Algernon. New York: Random House Publishing, 1984. Printed. Maus, Derek (ed.). Postmodernism. San Diego, CA: Greenhaven Press, 2001. Printed.

McGinnis, Wayne D. "The Source and Implications of Ice-nine in Vonnegut's Cat's Cradle". American Notes \& Queries, Vol. 13, Issue 3 (1974): 40. Printed.

Orwell, George. 1984. London: Arcturus Publishing, 2014. Printed.

Vonnegut, Kurt. Breakfast of Champions. New York: Random House Publishing, 2000. Printed.

Roberts, Adam. Science Fiction: The New Critical Idiom. Milton Park: Taylor \& Francis, 2006. Printed.

Shelley, Mary W. Frankenstein, Or, the Modern Prometheus. Worcestershire: Read Books, 2008. Printed.

Strand, Ginger. The Brothers Vonnegut: Science and Fiction in the House of Magic. New York: Farrar, Straus and Giroux, 2015. Printed.

Vonnegut, Kurt. Galapagos. New York: Random House Publishing, 1991. Printed.

Vonnegut, Kurt. The Sirens of Titan. New York: Random House Publishing, 2007. Printed. Vonnegut, Kurt. Cat's Cradle. New York: Random House Publishing, 2009. Printed.

Vonnegut, Kurt. Jailbird. New York: Random House Publishing, 2010. Printed.

Wells, Herbert. G. The War of the Worlds. Massachusetts: Trajectory classics, 2014. Printed. 


\title{
Milica Abramović
}

University of Belgrade

Faculty of Philology

\section{SCIENCE AND FICTION IN KURT VONNEGUT'S SCIENCE FICTION}

\begin{abstract}
Summary
Culture's attitude towards knowledge has changed with the advancement of science, and science fiction genre has become the one which records and illustrates that progression from the beginning to the postmodern age and further. One of the most important postmodern writers, Kurt Vonnegut, extensively uses the elements of science fiction in his works in order to parody the existential crisis of the postmodern individual who cannot lean on God or science anymore in the pursuit of understanding reality. Novels Player Piano and Cat's Cradle and their creation process are the representative examples of the clash of science and culture, having been written during the period when brothers Vonnegut worked for the same company - Kurt as a writer for the PR department and his brother Bernard Vonnegut as a leading scientist of the laboratory House of Magic. The deconstruction of the science fiction elements in the abovementioned novels and of the environment which had conditioned their creation indicates a specific relationship between science and fiction in this postmodern house of magic.
\end{abstract}

Keywords: science, fiction, science fiction, postmodernism, Vonnegut 